\title{
Strategi Pengembangan Ternak Kerbau di Kabupaten Tanah Laut
}

\section{(Development Strategy of Buffalo In Tanah Laut Regency)}

\author{
Fuzi Maulana Ash'ari ${ }^{1 *}$, Luthfi $^{2)}$, \& M. Husaini ${ }^{3)}$ \\ ${ }^{1)}$ Program Studi Agribisnis, Fakultas Pertanian \\ Universitas Islam Kalimantan Muhammad Arsyad Al Banjari Banjarmasin \\ 1)89fuzi@gmail.com \\ ${ }^{2 \& 3)}$ Program Studi Agribisnis Fakultas Pertanian Universitas Lambung Mangkurat Banjarbaru
}

\begin{abstract}
ABSTRAK
Tujuan penelitian ini adalah untuk mengetahui prioritas strategi pengembangan ternak kerbau di Kabupaten Tanah Laut menggunakan Focus Group Dicussion (FGD) dan analisis data dengan metode Analytical Hierarchy Process (AHP), Responden dalam penelitian ini sebanyak 12 (dua belas) responden yang terdiri dari Bagian Pengembangan Dinas Peternakan dan Kesehatan Hewan, Perwakilan Badan Perencanaan dan pembangunan Daerah (Bappeda) Kabupaten Tanah Laut, Akademisi dan Peternak Kerbau di Kabupaten Tanah Laut. Berdasarkan analisis menggunakan AHP didapatkan hasil tingkat peranan aktor berdasarkan urutan prioritas tertinggi adalah (1). Peternak: 0,42, (2). Dinas Peternakan dan Kesehatan Hewan Kabupaten Tanah Laut: 0,25, (3). Pedagang: 0,17 dan (4). Lembaga Pembiayaan: 0,09 dan (5). Penyedia Sarana Prasarana dan Input Peternakan: 0,07. Tingkat Peranan faktor berdasarkan urutan prioritas tertinggi adalah (1). Kebijakan Pemerintah: 0,31 (2). kondisi pasar: 0,29 (3). Sumberdaya Peternak: 0,25 dan (4). Teknologi Produksi: 0,15. Tingkat Peranan Strategi berdasarkan urutan prioritas tertinggi adalah (1). Peningkatan Populasi Ternak Kerbau: 0,646 dan (2). Peningkatan Kesejahteraan Peternak: 0,354. Tingkat Peranan strategi dalam pengembangan ternak kerbau di Kabupaten Tanah Laut berdasarkan urutan prioritas tertinggi adalah (1). Pengimplementasian Regulasi Pemasaran dan Pemotongan Ternak Kerbau Produktif: 0,203. (2). Memberikan Perangsang Produksi bagi Peternak: 0,154. (3). Perlindungan dan Pembukaan Lahan Baru Penggembalaan Ternak: 0,125. (4). Meningkatkan Teknologi Pengolahan Pakan: 0,119. (5). Meningkatkan Kegiatan Pemeriksaan/ Pelayanan Kesehatan dan Reproduksi Ternak: 0,115. (6). Optimalisasi Teknologi IB dan Intensifikasi Perkawinan Alam: 0,109. (7). Meningkatkan Pengetahuan dan Kelembagaan Peternak dalam Manajemen Usaha Peternakan: 0,089. (8). Optimalisasi Potensi Agrowisata Sebagai Salah Satu Daya Saing Daerah: 0,086.
\end{abstract}

Kata Kunci : Pengembangan, Ternak Kerbau, Analitycal Hierarchy Process (AHP).

\section{ABSTRACT}

The purpose of this study was to determine the priority of the development strategy for buffalo in Tanah Laut Regency using Focus Group Discussion (FGD) and data analysis using the Analytical Hierarchy Process (AHP) method. The respondents in this study were 12 (twelve) respondents consisting of sections Development of Animal Husbandry and Animal Health Service, Representative of the Regional Planning and Development Agency (Bappeda) of Tanah Laut Regency, Academics and Buffalo Breeders in Tanah Laut Regency. Based on the analysis using AHP, the results of the level of actor roles based on the highest priority order are (1). Breeder: 0.42, (2). Department of Animal Husbandry and Animal Health of Tanah Laut Regency: 0.25, (3). Traders: 0.17 and (4). Financing Institutions: 0.09 and (5). Providers of Infrastructure and Animal Husbandry Input: 0.07. The level of factor roles based on the highest priority order is (1). Government Policy: 0.31 (2). market conditions: 0.29 (3). Farmer Resources: 0.25 and (4). Production Technology: 0.15. The level of strategy roles based on the highest priority order is (1). Increase in Buffalo Population: 0.646 and (2). Increase in Farmer Welfare: 0.354. The level of strategic roles in the development of buffalo in Tanah Laut Regency based on the highest priority order is (1). Implementing Regulation on Marketing and Slaughter of Productive Buffalo Livestock: 0.203. (2). Provides Production Stimulation for Farmers: 0.154. (3). Protection and Opening of New Land for Livestock Grazing: 0.125. (4). Improve Feed Processing Technology: 0.119. (5). Increasing Animal Health and Reproduction Examination / Service Activities: 0.115. (6). Optimization of IB Technology and Intensification of Natural Marriage: 
0.109. (7). Increasing Knowledge and Institutional Farmers in Animal Husbandry Management: 0.089. (8). Optimization of the Potential of Agro-tourism as a Regional Competitiveness: 0.086.

Keywords: Development, buffalo, Analytical Hierarchy Process (AHP).

Article History Submitted: November 20, 2020 Approved with minor revision: December 11, 2020 Accepted: December 12, 2020 Published: December 30, 2020

\section{PENDAHULUAN}

Peternakan merupakan salah satu subsektor pertanian memiliki peranan yang penting dalam kegiatan ekonomi di pedesaaan. Peternakan merupakan salah satu bagian dari subsektor pertanian yang terus diupayakan untuk dikembangkan guna memenuhi kebutuhan protein hewani. salah satu usaha peternakan yang dapat mampu menunjang kebutuhan protein tersebut adalah peternakan ternak kerbau.

Kerbau merupakan salah satu aset nasional bidang peternakan yang ada diwilayah Kalimantan Selatan dan memiliki potensi besar untuk dikembangkan. Kerbau sebagai penghasil daging bagi konsumen umumnya belum begitu dibedakan dengan daging sapi, juga merupakan salah satu potensi yang patut dipertimbangkan. Ternak ini tersebar hampir di semua kabupaten dengan tingkat populasi yang berbeda (Hamdan \& Rohaeni, 2007).
Populasi kerbau di Indonesia terdiri dari kerbau perah dan kerbau potong. Populasi kerbau perah (River Buffalo) sangat sedikit, hanya sekitar $5 \%$ dari populasi yang ada, sedangkan populasi kerbau potong dan kerja (berupa kerbau lumpur/ swamp buffalo) mencapai hingga 95\%. Kerbau rawa adalah hewan ternak yang berpotensi baik untuk penggemukan atau sebagai ternak potong (Ihsan et. al., 2013).

Kerbau memiliki beberapa peranan utama secara nasional yaitu sebagai penghasil daging yang mendukung program pemerintah dalam hal swasembada daging selain daging sapi, sebagai ternak kerja, penghasil susu dan pupuk. Daging kerbau dapat dijadikan sebagai subtitusi dari daging sapi, kandungan gizi daging kerbau dan daging sapi relatif sama seperti yang disajikan pada Tabel 1.

Tabel 1. Perbandingan Kandungan Gizi Daging Kerbau dan Sapi

\begin{tabular}{lcc}
\hline Kandungan Gizi & Kerbau & Sapi \\
\hline Air & $84,0 \%$ & $66,0 \%$ \\
Protein & $18,7 \%$ & $18,8 \%$ \\
Lemak & $0,50 \%$ & $14,0 \%$ \\
Energi & $84 \mathrm{kkal}$ & $207 \mathrm{kkal}$ \\
\hline
\end{tabular}

Sumber: Rakhman, (2009).

Menurut Hamdan (2010) Ternak kerbau disamping sebagai potensi penghasil daging dan sumber pendapatan bagi peternak yang mengusahakannya, juga sebagai salah satu obyek wisata alam yang unik.

Kabupaten Tanah Laut merupakan salah satu kabupaten yang cukup potensial untuk pengembangan ternak kerbau, hal tersebut dikarenakan Kabupaten Tanah Laut memiliki luasan lahan rawa (belum termanfaatkan) seluas $168.789 \quad \mathrm{Ha}$ sedangkan lahan rawa yang termanfaatkan hanya sebesar $792 \mathrm{Ha}$ (BPS, 2015). Ketersedian lahan rawa yang luas merupakan potensi sumberdaya alam yang 
tidak ternilai dan harus dapat dimanfaatkan seoptimal mungkin. Melihat potensi yang ada, didukung adanya permintaan dan konsumsi daging kerbau maka Kabupaten Tanah Laut berpotensi sebagai salah satu pemasok ternak kerbau baik dalam bentuk daging kerbau maupun sebagai salah satu potensi agrowisata. Berdasarkan hal tersebut diatas rumusan masalah dalam penelitian ini adalah bagaimana strategi pengembangan ternak kerbau rawa di Kabupaten Tanah Laut provinsi Kalimantan Selatan. Tujuan penelitian ini adalah untuk mengetahui prioritas strategi pengembangan ternak kerbau di Kabupaten Tanah Laut menggunakan Focus Group Dicussion (FGD) dan analisis data dengan metode Analitycal Hierarchy Process (AHP),

\section{METODE PENELITIAN}

Penelitian ini dilakukan pada bulan Desember 2015 - Maret 2016 berlokasi di
Kabupaten Tanah Laut Provinsi Kalimantan Selatan.

Data yang digunakan dalam penelitian ini terdiri dari data primer dan data sekunder. Data primer diperoleh dari Focus Group Discussion (FGD), wawancara dan observasi langsung ke lapangan menggunakan kuesioner. Responden terdiri dari respoden pakar dan pelaku usaha ternak kerbau.

Responden pakar yang akan dijadikan responden menggunakan kriteria (Sarpitono, 2013):

a. Mempunyai pengalaman yang kompeten sesuai dengan bidang yang dikaji

b. Mempunyai reputasi, kedudukan/ jabatan dalam kompetensi dalam bidang yang dikaji

c. Memiliki kredibilitas yang tinggi, bersedia dan atau berada pada lokasi yang dikaji.

Tabel 2. Daftar Responden

\begin{tabular}{lc}
\hline \multicolumn{1}{c}{ Responden Pakar AHP } & Jumlah \\
\hline Dinas Peternakan Kabupaten Tanah Laut & 1 \\
\hline Bappeda Kabupaten Tanah Laut & 1 \\
\hline Akademisi & 2 \\
\hline Peternak/ Pelaku Usaha & 8 \\
\hline
\end{tabular}

Data sekunder yang digunakan adalah data umum yang mendukung dalam penelitian terkait agribisnis kerbau di Kabupaten Tanah Laut meliputi perkembangan populasi dan produksi, serta data-data yang berasal dari Dinas Peternakan Provinsi Kalimantan Selatan dan Dinas Peternakan dan Kesehatan Hewan Kabupaten Tanah Laut, Badan Pusat Statistik.

Sebelum menentukan alternatif strategi untuk mengetahui urutan prioritas dalam penentuan strategi pengembangan ternak kerbau di Kabupaten Tanah Laut, maka terlebih dahulu dilakukan Focus Group Discussion (FGD) kemudian Perumusan strategi pengembangan ternak kerbau di Kabupaten Tanah Laut dilakukan dengan Analytical Hierarchy Proses
(AHP). Dengan menggunakan Analytical Hierarchy Proses (AHP), proses keputusan komplek dapat diuraikan menjadi keputusan-keputusan lebih kecil yang dapat ditangani dengan mudah.

Menurut Permadi (1992) Analytical Hierarchy Proses (AHP) merupakan suatu metode pengambilan keputusan yang dapat membantu kerangka berpikir manusia. Piranti metode ini adalah sebuah hirarki fungsional dengan persepsi manusia sebagai input utamanya. Metode Analytical Hierarchy Proses (AHP) memakai persepsi manusia yang dianggap expert sebagai input utamanya. Kriteria disini mengacu pada orang yang mengerti benar permasalahan yang diajukan, merasakan akibat suatu masalah atau punya kepentingan terhadap masalah tersebut. 
Karena menggunakan input kualitatif (persepsi manusia), maka selain hal-hal yang kuantitatif, metode ini juga dapat mengolah hal-hal kualitatif. Bisa dikatakan bahwa metode Analytical Hierarchy Proses (AHP) merupakan suatu metode pengambilan keputusan yang komprehensif, memperhitungkan hal-hal kuantitatif sekaligus kualitatif.

Responden pakar AHP dipilih dengan kriteria bahwa responden tersebut berkompeten serta dapat memberikan gambaran informasi tentang hambatan dan peluang serta strategi pengembangan ternak kerbau.

\section{HASIL DAN PEMBAHASAN}

Berdasarkan hasil Focus Group Discussion (FGD) didapatkan alternatif strategi sebagai berikut:

a. Meningkatkan teknologi pengolahan pakan ternak b. Optimalisasi potensi agrowisata sebagai salah satu daya saing daerah

c. Meningkatkan pengetahuan dan kelembagaan dalam manajemen usaha peternak

d. Memberikan perangsang produksi bagi peternak

e. Perlindungan dan pembukaan lahan baru penggembalaan ternak

f. Pengimplementasian regulasi pemasaran dan pemotongan ternak kerbau produktif

g. Meningkatkan kegiatan pemeriksaan/ pelayanan kesehatan dan reproduksi ternak

h. Optimalisasi teknologi Inseminasi Buatan (IB) dan intensifikasi perkawinan alam

Berdasarkan Analitical Hierrchy Prosess (AHP) didapatkan hasil urutan prioritas dalam strategi pengembangan ternak kerbau di Kabupaten Tanah Laut, yang disajikan pada Gambar 1.

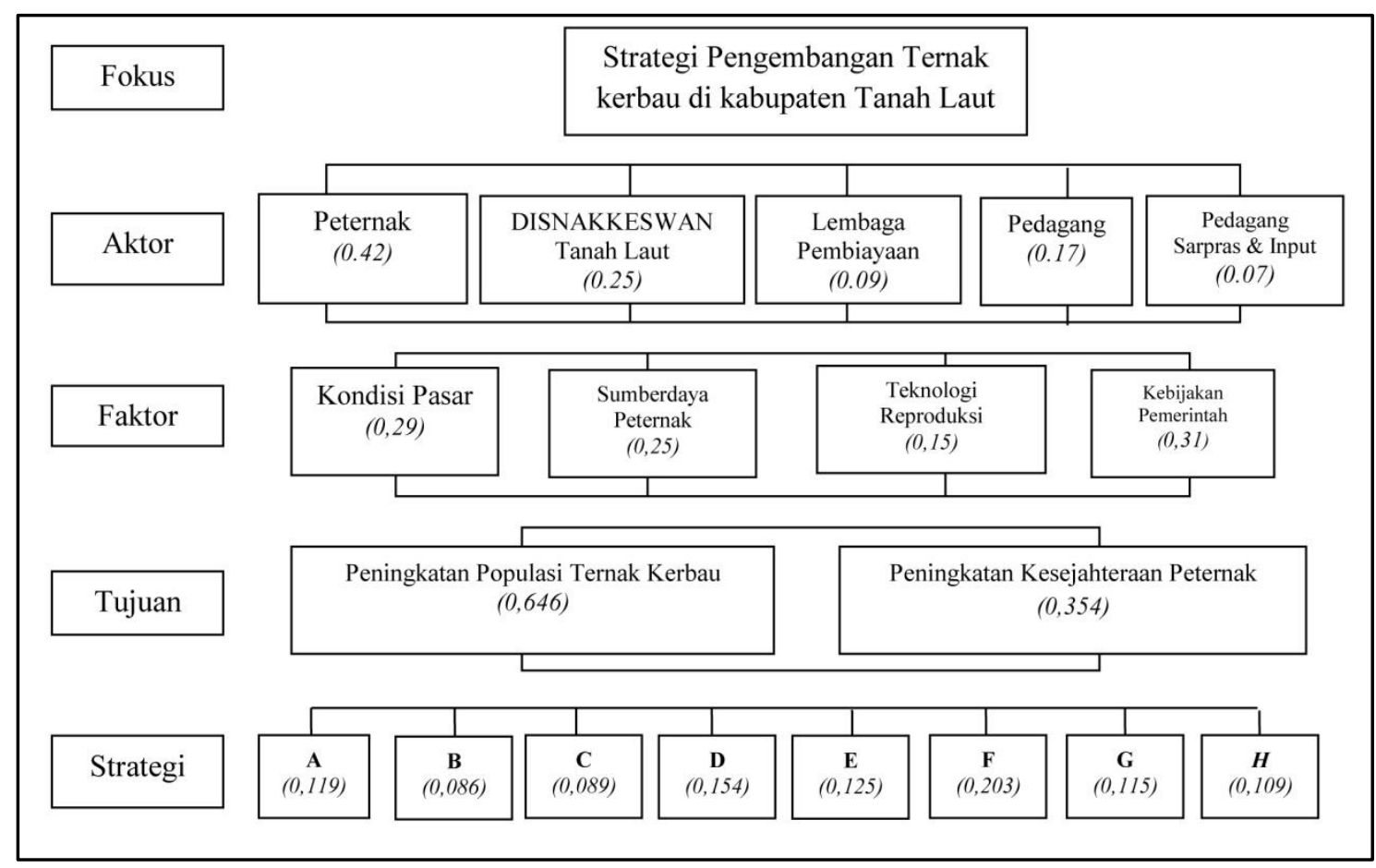

Gambar 1. Struktur Hirarki Strategi Pengembangan Ternak Kerbau di Kabupaten Tanah Laut

Berdasarkan urutan prioritas hasil pengolahan Analytical Hierarchy Proses (AHP) , strategi pengembangan ternak kerbau di Kabupaten Tanah Laut adalah sebagai berikut: (F). Pengimplementasian regulasi pemasaran dan pemotongan ternak kerbau produktif dengan nilai 0,203. (D). Memberikan pendorong produksi bagi peternak dengan nilai 0,154. (E). Perlindungan dan pembukaan lahan baru 
penggembalaan ternak dengan nilai 0,125 . (A). Meningkatkan teknologi pengolahan pakan dengan nilai 0,119. (G). Meningkatkan kegiatan pemeriksaan/ pelayanan kesehatan dan reproduksi ternak dengan nilai $0,115, \quad(\mathbf{H})$. Optimalisasi teknologi IB dan intensifikasi perkawinan alam dengan nilai 0,109 , (C). Meningkatkan pengetahuan dan kelembagaan peternak dalam manajemen usaha peternakan dengan nilai 0,089, (B). Optimalisasi potensi agrowisata sebagai salah satu daya saing daerah dengan nilai 0,086. Implikasi dari masing-masing strategi tersebut dijabarkan sebagai berikut: Pengimplementasian regulasi pemasaran dan pemotongan ternak produktif.

Berdasarkan Peraturan Pemerintah No. 95 Tahun 2012 tentang kesehatan masyarakat veteriner dan kesejahteraan hewan pasal 9 ayat 2 yang menyebutkan hewan potong yang layak untuk dipotong memenuhi kriteria paling sedikit (a). tidak memperlihatkan gejala penyakit hewan menular dan/ atau Zoonisis, (b). Bukan ruminansia besar betina anakan atau betina produktif, (c). Tidak dalam keadaan bunting, (d). Bukan hewan yang dilindungi berdasarkan ketentuan peraturan perundang-undangan.

Selama ini di setiap pasar-pasar hewan pasti kita ada menjumpai hewan ternak yang terjual atau terpaksa dijual dalam kondisi atau keadaan yang masih produktif untuk menghasilkan bibit ternak kerbau, ini tak terlepas disebabkan kebutuhan ekonomi petani-peternak kerbau. Hal demikianlah yang harus disiasati oleh pemerintah demi menumbuhkan kesadaran petani-peternak untuk tidak menjual ternak kerbau produktif dengan melakukan penyuluhan peraturan pemerintah tentang pemotongan ternak betina produktif serta memfasilitasi atau memudahkan penyediaan peminjaman dana dari lembaga penunjang untuk petanipeternak yang membutuhan kredit lunak demi menyelamatkan ternak kerbau yang masih produktif untuk menghasilkan bibit ternak yang berkualitas.
1. Memberikan pendorong produksi bagi peternak

Menurut Luthfi, (2006), suatu teknologi baru akan dimanfaatkan petani kalau teknologi baru tersebut cukup memberi perangsang, baik perangsang ekonomi maupun non ekonomis. Perangsang yang dapat secara efektif mendorong petani menaikkan produksinya adalah terutama bersifat ekonomis yakni (a). Perbandingan harga yang menguntungkan, (b). Bagi hasil yang wajar, (c). Tersedianya barang dan jasa yang ingin dibeli oleh petani dan keluarganya, sedangkan perangsang yang bersifat non ekonomis adalah (a). Pendidikan kesejahteraan keluarga bagi wanita, (b). Penghargaan masyarakat terhadap petani.

$$
\text { Beberapa contoh perangsang }
$$

produksi bagi peternak kerbau di Kabupaten Tanah Laut yang bisa diimplikasikan adalah kemudahan mendapatkan kredit untuk mengembangkan usaha peternakan dan kemitraan serta adanya jaminan harga ternak dan asuransi ternak.

2. Perlindungan dan pembukaan lahan baru penggembalaan ternak

Pada umumnya ternak ruminansia (sapi dan kerbau) membutuhkan pakan berupa hijauan dalam jumlah minimal $10 \%$ dari bobot badannya sedangkan konsentrat sebesar 1-2\% dari bobot badannya. Pemeliharaan ternak kerbau di Kabupaten Tanah Laut kebanyakan dilakukan secara ekstensif atau tradisional yang mana semua aktivitas mulai perkawinan serta perkembangbiakan dan pakan dilakukan di padang penggembalaan. Masalah yang dihadapi oleh peternak terutama ternak kerbau rawa di Desa Banua Raya Kecamatan Bati-Bati adalah adanya konversi lahan yang awalnya padang penggembalaan bertranformasi menjadi lahan pemukiman yang menyebabkan adanya penurunan jumlah luasan padang penggembalaan ternak kerbau yang selama ini telah dimanfaatkan secara turun temurun oleh peternak.. Oleh karena itu sangat diperlukan peran pemerintah 
sebagai pemangku kebijakan untuk dapat kiranya memberikan payung hukum yang memadai berdasarkan rencana tata ruang dan wilayah (RTRW) yang dikeluarkan oleh pemerintah Kabupaten Tanah Laut tidak mencantumkan dengan jelas tentang wilayah pengembangan peternakan dan lahan penggembalaan.

3. Meningkatkan teknologi pengolahan pakan

Pakan memiliki peranan yang sangat penting dalam pengembangan ternak, karena pakan salah satu penentu keberhasilan suatu usaha peternakan selain faktor perkawinan dan faktor manajemen, pada usaha peternakan intensif, faktor pakan memiliki persentase sampai dengan sebesar $70 \%$ bahkan lebih dari total biaya produksi suatu usaha peternakan modern. Untuk mensiasati tingginya harga pakan ternak maka para peternak untuk dianjurkan meramu pakan sendiri dengan memanfaatkan teknologi pengolahan pakan ternak sebagai contoh pembuatan hay atau silase hijau pakan ternak, dengan pemanfaatan teknologi pengolahan pakan akan memudahkan peternak dalam hal penyediaan pakan ternak pada musimmusim tertentu, pada musim kemarau contohnya, berlimpahnya hijauan pakan ternak sehingga tidak mampu terserap oleh seluruh ternak kerbau yang dimiliki peternak,oleh karena itu dibutuhkan pengolahan pakan ternak demi ketersediaan pakan pada musim kemarau yang mana hijauan akan sedikit sulit untuk didapatkan.

Upaya yang dapat dilakukan dalam meningkatkan teknologi pengolahan pakan adalah dengan memberikan pelatihan kepada petani peternakn tentang terknologi pengolahan pakan, melakukan transfer teknologi kepada peternak oleh peneliti dan akademisi yang memiliki kemampuan dan kompetensi dalam hal teknologi pengolahan pakan ternak ruminansia.

4. Meningkatkan kegiatan pemeriksaan atau pelayanan kesehatan dan reproduksi ternak

Ternak kerbau yang dipelihara di Kabupaten Tanah Laut kebanyakan bersifat ekstensif maka dalam rangka kegiatan pemeriksaan kesehatan/ pelayanan kesahatan serta reproduksi ternak akan sedikit mengalami kesulitan karena sistem pemeliharaan yang dilepas dan digembalakan dipadang penggembalaan yang luas, sifat ternak kerbau yang liar dan akan menjauh ketika didekati oleh manusia bukan pemiliknya maka hal tersebut menjadi salah satu yang menghambat pemeriksaan kesehatan.

Kegiatan yang dapat diterapkan dalam strategi ini yakni dengan membekali ilmu pengetahuan dasar tentang kesehatan hewa ternak kerbau kepada peternak, sehingga peternak dapat melakukan pertolongan pertama dalam hal penanganan penyakit ternak kerbau sehingga terhindar dari penyakit yang dapat menyebabkan kematian pada ternak

5. Optimalisasi teknologi IB dan intensifikasi kawin alam (INKA)

Salah satu kelemahan utama yang dimiliki oleh petani-peternak rakyat di Indonesia secara umum adalah belum diterapkannya manajemen tatalaksana usaha peternakan yang baik dan benar, sehingga usaha peternakan belum memberikan kontribusi yang besar terhadap upaya meningkatkan kesejahteraan petani-peternak. Usaha peternakan umumnya dikelola secara tradisional (apa adanya) yang sangat minim dengan sentuhan teknologi dan dilakukan sebagai usaha sampingan.

Intensifikasi kawin alam (INKA) adalah upaya peningkatan populasi ternak sapi dan kerbau melalui pemakaian dan distribusi pejantan terseleksi dari bangsa sapi dan kerbau lokal. (Kementrian Pertanian, 2016)

Beberapa kegiatan yang dapat diimplikasikan pada strategi ini adalah dengan mengoptimalkan peran peternak dan inseminator melaksanakan proses inseminasi buatan, memberikan peternak pengetahuan atau ketermpilan untuk mendeteksi birahi (estrus) pada ternak secara dini serta mendatangkan pejantan dari luar kelompok ternak secara periodik 
demi menghindari perkawinan sedarah / inbreeding pada ternak kerbau.

6. Meningkatkan pengetahuan dan kelembagaan peternak dalam manajemen usaha peternakan.

Menurut Rizal (2016) umumnya petani-peternak rakyat di Indonesia mengelola usahanya dengan sederhana dan tanpa dilandasi oleh pengetahuan teknis di bidang peternakan yang memadai. Usaha peternakan dikelola berdasarkan kebiasaan yang berlangsung secara turun temurun. Hal iniyang menjadi salah satu faktor utama yang menghambat perkembangan peternakan secara progresif. Upaya yang dapat dilakukan untuk meningkatkan pengetahuan dan keterampilan petanipeternak adalah dengan melakukan penyuluhan dan pelatihan yang terstruktur dengan baik. Salah satu bentuk kegiatan yang efektf untuk ditularkan ke petanipeternak rakyat adalah dengan membuat sebuah percontohan (pilot project) peternakan terpadu yang dikelola secara

\section{Tingkat Peranan Aktor dalam Pengembangan Ternak Kerbau di Kabupaten Tanah Laut}

Berdasarkan hasil perhitungan Analitycal Hierarchy Process (AHP), perbandingan antar unsur "aktor" berdasarkan "fokus" pengembangan ternak kerbau di Kabupaten Tanah Laut yakni yang pertama adalah Peternak Kerbau di Kabupaten Tanah Laut dengan nilai 0,42, sedangkan prioritas selanjutnya adalah Dinas Peternakan dan Kesehatan Hewan Kabupaten Tanah Laut dengan nilai 0,25 dilanjutkan oleh pedagang dengan nilai 0,17 serta lembaga pembiayaan dengan nilai 0,09 dan penyedia sarana prasarana dan input peternakan dengan nilai 0,07

Peternak dianggap menjadi aktor yang berperan penting dalam pengembangan ternak kerbau di Kabupaten Tanah Laut karena dianggap sebagai pelaku on-farm yang merupakan subsistem utama karena produk-produk peternakan yang digunakan oleh konsumen pada dasarnya dihasilkan oleh subsistem ini dan tanpa subsistem ini tidak mungkin ada professional dengan beberapa sentuhan teknologi tepat guna dibidang peternakan.

Beberapa kegiatan yang dapat diimplikasikan pada strategi ini adalah melakukan penyuluhan secara intens demi meningkatkan transfer ilmu pengetahuan tentang manajemen usaha peternakan kerbau, melakukan bimbingan teknis pemeliharaan kepada ternak dan memberikan pendidikan dan pelatihan teknis kepada peternak maupun penyuluh peternak

7. Optimalisasi potensi agrowisata sebagai salah satu daya saing daerah

Beberapa kegiatan yang dapat diimplikasikan pada strategi optimalisasi potensi agrowisata sebagai salah satu daya saing daerah adalah melakukan kegiatan promodi media cetak atau elektronik serta media sosial untuk meningkatkan kunjungan pengunjung agrowisata ternak kerbau terutama kerbau rawa di desa Banua Raya Kecamatan Bati-Bati

subsistem agribisnis hulu dan hilir (Soekardono, 2009).

Tingkat Peranan Faktor dalam Pengembangan Ternak Kerbau di Kabupaten Tanah Laut

Berdasarkan hasil perhitungan Analitycal Hierarchy Process (AHP), perbandingan antar unsur "faktor" berdasarkan "aktor" pengembangan ternak kerbau di Kabupaten Tanah Laut yakni urutan pertama adalah kebijakan pemerintah dengan nilai 0,31 dan urutan kedua kondisi pasar dengan nilai 0,29 dilanjutkan dengan sumberdaya peternak dengan nilai 0,25 dan teknologi produksi dengan nilai 0,15 .

Kebijakan pemerintah dinilai sebagai prioritas pertama dibandingkan faktor lainnya, menurut Mayulu \& Sutrisno (2016) dikarenakan secara umum pengembangan suatu jenis usaha dipengaruhi oleh berbagai faktor, salah satunya adalah dukungan aturan dan kebijakan (rules and polices) pemerintah. Dalam hal ini kemauan pemerintah (governmental will) dan legislatif berperan 
penting, selain lembaga penelitian dan perguruan tinggi. Keberhasilan pengembangan usaha ternak ditentukan oleh faktor dukungan kebijakan yang strategis yang mencakup tiga dimensi utama agribisnis yakni kebijakan pasar input, budidaya serta pemasaran dan perdagangan dengan melibatkan pemerintah, swasta dan masyarakat peternak. Menurut Soekardono (2009), kebijakan pemerintah dalam hal pengembangan peternakan di masa yang akan datang harus dikuatkan dengan political will pemerintah sehingga subsistem kelembagaan menjadi kondusif untuk pengembangan peternakan.

Selain kebijakan pemerintah, kondisi pasar menjadi faktor terpenting kedua dikarenakn kondisi pasar dapat dijadikan sebagai perangsang produksi untuk peternak kerbau di Kabupaten Tanah Laut sekaligus menjadi motivasi usaha dalam pengembangan ternak kerbau.

\section{Tingkat Peranan Tujuan dalam Pengembangan Ternak Kerbau di Kabupaten Tanah Laut}

Berdasarkan hasil perhitungan Analitycal Hierarchy Process (AHP), perbandingan antar unsur "Tujuan" berdasarkan "Faktor" pengembangan ternak kerbau di Kabupaten Tanah Laut yaitu urutan pertama adalah peningkatan populasi ternak kerbau dengan nilai 0,646 dan urutan yang kedua adalah peningkatan kesejahteraan peternak dengan nilai 0,354. Dengan meningkatnya populasi ternak kerbau di Kabupaten Tanah Laut maka akan mendorong terciptanya swasembada daging

Tujuan peningkatan kesejahteraan peternak merupakan salah satu aspek yang harus diperhatikan di dalam cara pandang agribisnis peternakan selain ternak sebagai objek yang harus ditingkatkan produksi dan produktivitasnya (Soekardono, 2009). Sedangkan menurut (Luthfi, 2006) meningkatkan pendapatan dan taraf hidup petani melalui pengembangan system agribisnis dan usaha-usaha agribisnis adalah salah satu tujuan pembangunan pertanian.

Terkait tujuan dengan prioritas pertama yakni peningkatan populasi ternak kerbau dengan nilai 0,646 berbagai upaya telah dilakukan salah satunya adalah dengan melakukan penyediaan obat dan vaksin serta penyediaan sarana dan prasarana perkawinan suntik (inseminasi buatan).

\section{KESIMPULAN}

Strategi pengembangan ternak kerbau di Kabupaten Tanah Laut yang dianalisis dengan Analytical Hierarchy Process (AHP) didapatkan hasil sebagai berikut:

Tingkat peranan aktor berdasarkan urutan prioritas tertinggi adalah (1). Peternak: 0,42, (2). Dinas Peternakan dan Kesehatan Hewan Kabupaten Tanah Laut: 0,25, (3). Pedagang: 0,17 dan (4). Lembaga Pembiayaan: 0,09 dan (5). Penyedia Sarana Prasarana dan Input Peternakan: 0,07.

Tingkat Peranan faktor berdasarkan urutan prioritas tertinggi adalah (1). Kebijakan Pemerintah: 0,31 (2). kondisi pasar : 0,29 (3). Sumberdaya Peternak: 0,25 dan (4). Teknologi Produksi: 0,15.

Tingkat Peranan Strategi berdasarkan urutan prioritas tertinggi adalah (1). Peningkatan Populasi Ternak Kerbau: 0,646 dan (2). Peningkatan Kesejahteraan Peternak: 0,354. Tingkat Peranan strategi dalam pengembangan ternak kerbau di Kabupaten Tanah Laut berdasarkan urutan prioritas tertinggi adalah (1). Pengimplementasian Regulasi Pemasaran dan Pemotongan Ternak Kerbau Produktif: 0,203. (2). Memberikan Perangsang Produksi bagi Peternak: 0,154. (3). Perlindungan dan Pembukaan Lahan Baru Penggembalaan Ternak: 0,125. (4). Meningkatkan Teknologi Pengolahan Pakan: 0,119. (5). Meningkatkan Kegiatan Pemeriksaan/ Pelayanan Kesehatan dan Reproduksi Ternak: 0,115. (6). Optimalisasi Teknologi IB dan Intensifikasi Perkawinan Alam: 0,109. (7). 
Meningkatkan Pengetahuan dan Kelembagaan Peternak dalam Manajemen Usaha Peternakan: 0,089. (8). Optimalisasi Potensi Agrowisata Sebagai Salah Satu Daya Saing Daerah: 0,086.

\section{DAFTAR PUSTAKA}

Hamdan, A., \& Rohaeni, E. (2007). Potensi Dan Peluang Pengembangan Ternak. 1990, 77-82.

Ihsan, M. N., Nugroho, H., Produksi, B., Fakultas, T., \& Ub, P. (2013). Aspek Kinerja Reproduksi dan Ukuran Tubuh di Kecamatan Tempursari Kabupaten Lumajang. Ternak Tropika, 14(1), 21-28.

Kementrian Pertanian. (2016). Petunjuk Teknis Pengumpulan dan Penyajian Data Fungsi Peternakan dan Kesehatan Hewan (Vol. 4, Issue 1).

Luthfi. (2006). Dinamika Pembangunan Pertanian dan Pedesaan. Pustaka Banua. Banjarbaru Kalimantan Selatan.

Mayulu, H., \& Sutrisno, C. I. (2016). Kebijakan Pengembangan Peternakan Sapi Potong di Indonesia. Jurnal Penelitian Dan Pengembangan Pertanian, 29(1), 124352. https://doi.org/10.21082/jp3.v29n1.20 10.p\%p.
Permadi, B. (1992). Analitical Hierarchy Proses (AHP). Pusat Antar Universitas, Studi Ekonomi Universitas Indonesia. Jakarta.

Rakhman. A. Gazali., 2009. Kajian Investasi Usaha Ternak Kerbau Rawa (Kerbau Kalang) di Kabupaten Hulu Sungai Utara. Tesis Program Magister Ekonomi Pertanian Pascasarjana Universitas Lambung Mangkurat. Banjarbaru.

Republik Indonesia, (2016). Peraturan Pemerintah No. 95 Tahun 2012 tentang kesehatan masyarakat veteriner dan kesejahteraan hewan. Sekretariat Negara, Jakarta.

Rizal, M. (2016). Optimalisasi Penerapan Teknologi Inseminasi Buatan pada Peternakan Rakyat. Pidato Pengukuhan Guru Besar Universitas Lambung Mangkurat.

Sarpitono. (2013). Strategi Pengembangan Sistem Agribisnis Peternakan Sapi Perah di Provinsi Bengkulu [Fakultas Pertanian UNIB]. http://repository.unib.ac.id/1186/

Soekardono. (2009). Ekonomi Agribisnis Peternakan - Teori dan Aplikasinya. Akademika Pressindo. 